\title{
Cross-Species Amplification of Coconut Microsatellite Markers in Rattans
}

\author{
By M. Nageswara RaO ${ }^{1), 3), *)}$, B. T. Ramesha ${ }^{2)}$, G. RaviKanth ${ }^{4)}$, K. N. GaneshaiaH ${ }^{3), 4), 5)}$ and R. Uma ShaAnkeR ${ }^{2), 4), 5)}$
}

(Received 22 ${ }^{\text {th }}$ August 2006)

\begin{abstract}
Summary
Cross-species amplification of microsatellite loci is considered to be a time-saving as well as a cost-effective approach for developing locus specific markers for new species. In an attempt to identify molecular markers to determine gene flow events and genetic differentiation of populations in rattans, microsatellite primer pairs developed for Cocos nucifera (Arecaceae) were examined for cross-species amplification in rattans. Of the six microsatellite primer pairs screened, two (CNZ34 and CN2A5) yielded good cross-species amplification across different rattan genera and species from South and Southeast Asia. Based on microsatellite-specific PCR amplification products, cluster analysis was performed. The dendrogram indicated a clear grouping of rattans based on their genera and species. The coconut locus specific primer pairs could be successfully used to construct molecular differentiation of rattan genera across different geographical locations.
\end{abstract}

Key words: Cocos nucifera, Cross-amplification, Genetic differentiation, Microsatellite markers, Rattans.

\section{Introduction}

Rattans, a group of trailing or climbing palms, belong to the family Arecaceae (Palmae). With about 600 species in 13 genera, their distribution is restricted to tropical and sub-tropical Asia and equatorial Africa (DRANSFIELD, 1996). Very few rattans have been investigated cytologically to determine the chromosome numbers, diploid numbers vary between 22-24 (RAO and RAO, 1998). Majority of them are dioecious (RAVIKANTH et al., 2001). Rattans form an important source of livelihood for the economically and socially weaker sections of the community in South and Southeast Asia. India is one of the richest sources of rattans, harboring over 70 species in five genera, viz., Calamus, Daemonorops, Zalacca, Korthalsia and Plectocomia (RENUKA, 2001). They comprise of more than fifty percent of the total palm taxa in India (BASU, 1985) and occur in the Western Ghats, sub-Himalayan hills, valleys of Eastern and Northeastern India and the Andaman and Nicobar Islands. Their elastic stems are highly valued for light-

1) University of Florida, IFAS, Citrus Research and Education Centre, 700 Experiment Station Road, Lake Alfred, FL-33850, USA.

2) Department of Crop Physiology, University of Agricultural Sciences, Bangalore-560065, India.

3) Department of Genetics and Plant Breeding, University of Agricultural Sciences, Bangalore-560065, India.

4) Ashoka Trust for Research in Ecology and Environment, No $659,5^{\text {th }}$ Main, Hebbal, Bangalore-560024, India.

5) Jawaharlal Nehru Centre for Advanced Scientific Research, Jakkur, Bangalore-560064, India.

*) Author for correspondence: Tel. 1-863-956-1151; Fax: 1-863956-4631; E-mail: mnrao@crec.ifas.ufl.edu. ness, strength and durability, forming a major source for furniture industry. As the world's demand for rattan products is increasing, there is tremendous pressure on the native populations of rattans. Extensive extraction, loss of habitats and other anthropogenic activities have severely threatened rattan genetic resources in India. The threat is further accentuated by the fact that rattans are dioecious and because of their premature harvest, they rarely flower and fruit. A number of endemic rattan species are already threatened and are on the verge of becoming endangered (LAKSHMANA, 1995; LYNGDOH et al., 2005). Few studies have addressed the population genetic consequences of habitat fragmentation in these species (WICKNESWARI and BOYLE, 2000; RAVIKANTH et al., 2001; LYNGDOH et al., 2005). One of the major constraints in population genetic studies of rattans is the lack of availability of precise molecular markers.

Locus specific markers such as microsatellites could be of great utility not only in determining the levels of genetic diversity but also in unraveling the genetic structure of the populations and in estimating the levels of gene flow. They are capable of detecting a large number of alleles with high reproducibility and transportability between species (CLAUSS et al., 2002). They are also markers of choice for 'DNA fingerprinting' applications, and are used to investigate questions related to effective population size, structure, migration, colonization rates and mating systems (TURPEINEN et al., 2001; Clauss et al., 2002). Despite their global applicability, the development and utility of microsatellites for fingerprinting or alternatively converting them into STMS (Sequence Tagged Microsatellite Sites) are both expensive and time consuming (PEAKALL et al., 1998).

It has been reported that the microsatellite flanking regions in which the primers are placed evolve much more slowly, and therefore might permit cross-species amplification in species other than the one for which it has been designed (PEAKALL et al., 1998; KARHU et al., 2000; TURPEINEN et al., 2001). This approach offers a potential for low cost development of microsatellite markers for species with little or no information on sequence, through the screening of primers from different sources. Increasing number of workers have taken advantage of this to evaluate whether already available markers could provide cross-amplification in the species in question and have reported that the cross-species microsatellite amplification may resolve ecological and evolutionary questions (SCOTT et al., 2001; WILLIAMSON et al., 2002; Clauss et al., 2002; JonEs et al., 2002). Against this backdrop, we attempted to examine the cross-amplification of microsatellite markers developed for Cocos nucifera against rattans as both belong to the family Arecaceae and also to study the relative molecular differentiation of the various rattan genera. 


\section{Materials and Methods}

Six pairs of previously published coconut (Cocos nucifera) species specific microsatellite markers viz., CNZ05, CNZ19, CNZ34, CNZ46, CN2A5 and CN1G4 (TEULAT et al., 2000; Table 1) were selected for crossspecies amplification in rattans. In the present study, we used four genera of rattans [Korthalsia (K. laciniosa), Zalacca (Z. zalacca), Daemonorops (D. kurzianus) and Calamus (Calamus simplicifolia, C. mannan, C. thwaitesii, C. erectus and C. palustris)]. Among the genera, Zalacca and Daemonorops are geographically distributed in Northeast India, Korthalsia in Andaman and Nicobar Islands, while, the genera Calamus is found to be widely distributed across regions of Western Ghats in India to Malaysia (RENUKA, 2001).

Leaf samples of the rattan species, C. thwaitesii, were obtained from primary field collection in the Western Ghats, India. Leaf samples of other Calamus species and rattan genera, one each, were obtained from herbarium samples from Kerala Forest Research Institute (KFRI), Kerala, India. Genomic(g)-DNA from 100-150 mg mature dry leaf sample was extracted in $1.5 \mu \mathrm{l}$ Eppendorf tube using a modified CTAB method (DoYLE and DoYle, 1987). The dry leaf material was ground with liquid nitrogen and was digested at $65^{\circ} \mathrm{C}$ for 45 min with extraction buffer $[10 \mathrm{mM}$ Tris-HCl $\mathrm{pH} 8.0$, 20 mM EDTA pH 8.0, $1.4 \mathrm{M} \mathrm{NaCl}, 2 \%$ CTAB, 1\% PVP40 and $2 \% \beta$-mercaptoethanol (due to the high content of tannins in dry leaf samples, the best results were achieved by increasing the concentration of $\beta$-mercaptoethanol to $2 \%$ and removing SDS from the extraction buffer)]. To improve the quality of g-DNA extraction, the chloroform-isoamyl alcohol step was done twice. The gDNA was precipitated by addition of chilled isopropanol and the pellet was washed twice with $70 \%$ ethanol prior to suspension in $10 \mathrm{mM}$ Tris- $\mathrm{HCl}(\mathrm{pH} \mathrm{8.0)}$. The g-DNA was again repreciptated with chilled isopropanol and 7.5 M sodium acetate, the pellet washed with $70 \%$ ethanol before resuspension in $10 \mathrm{mM}$ Tris- $\mathrm{HCl}(\mathrm{pH} 8.0)$.

The microsatellite primer pair nucleotide sequences (TEUlAT et al., 2000) were synthesized using custom- made oligonucleotides by Sigma Aldrich, USA. All the six microsatellite primer pairs were tested for locus specific amplification using known molecular weight marker (50 bp Orange, Genetex, USA). The microsatellite loci names, nucleotide sequences, their repeat types and their expected PCR product size ranges are depicted in Table 1.

The PCR amplification was carried out in $15 \mu \mathrm{l}$ volume reaction mixture containing $50 \mathrm{ng}$ template DNA, $0.3 \mu \mathrm{M}$ forward primer, $0.3 \mu \mathrm{M}$ reverse primer, $1.5 \mathrm{mM}$ $\mathrm{MgCl}_{2}, 0.5 \mathrm{U}$ of Taq DNA polymerase and $100 \mu \mathrm{M}$ of each dNTP. PCR regime consisted of an initial denaturation at $94^{\circ} \mathrm{C}$ for 2 min followed by 35 cycles of $40 \mathrm{sec}$ denaturation at $94^{\circ} \mathrm{C}, 1 \mathrm{~min}$ annealing at $54^{\circ} \mathrm{C}$ and 2 min elongation at $72^{\circ} \mathrm{C}$. Final elongation was carried out at $72^{\circ} \mathrm{C}$ for $10 \mathrm{~min}$. Of the $15 \mu \mathrm{l} \mathrm{PCR}$ reaction products, $5 \mu \mathrm{l}$ were separated on a $10 \%$ polyacrylamide gel and electrophoresed at $50 \mathrm{~mA}$ constant power for six hours. The electrophoresed polyacrylamide gels were silver stained and further analyzed for estimating crossspecies amplification and to identify, if any, geographical differentiation in rattans from South and Southeast Asia. At each of the PCR amplified microsatellite locus, the frequency of each allele was computed and compared. The mean number of alleles per locus and polymorphic percentage for each primer pair were determined using POPGENE version 1.32 (YEH et al., 1999). The genetic differentiation among various rattan genera and species were analyzed using software, STATISTICA version 4.5 (STATSOFT, 1993). Based on microsatellite specific PCR amplification products, cluster analysis was performed following Ward's algorithm (SNEATH and SOKAL, 1973). For phylogeny reconstruction, the data was subjected to parsimony analysis using Winclada version 1.00.08 (NIXON, 2000).

\section{Results and Discussion}

The present work intended to determine the extent to which pairs of primers designed for the amplification of microsatellite loci in coconut can be used for assessing

Table 1. - Coconut microsatellite primer pair sequences, repeat type and size range, used for crossspecies amplification in rattans (adopted from TEULAT et al., 2000).

\begin{tabular}{|c|c|c|c|}
\hline $\begin{array}{l}\text { Sl. } \\
\text { No }\end{array}$ & Repeal Motif & Primer pair sequence & $\begin{array}{l}\text { Size range } \\
\text { (bp) }\end{array}$ \\
\hline 1 & $(\mathrm{CT})_{15}(\mathrm{GT})_{7}$ & $\begin{array}{l}\text { CNZ34F CATGTCGATAATTATACCCAA } \\
\text { CNZ34R TGCAAATATGAATGCAAACAC }\end{array}$ & $131-185$ \\
\hline 2 & $(\mathrm{CT})_{17}(\mathrm{GT})_{7}$ & $\begin{array}{l}\text { CNZ05F CTTATCCAAATCGTCACAGAG } \\
\text { CNZ05R AGGAGAAGCCAGGAAAGATTT }\end{array}$ & $151-178$ \\
\hline 3 & $(\mathrm{CT})_{15}(\mathrm{CA})_{5} \mathrm{CT}(\mathrm{CA})_{3}(\mathrm{CT})_{2}(\mathrm{CA})_{6}$ & $\begin{array}{l}\text { CNZ19F GAAGAAGGTGCTGGTTCTGTC } \\
\text { CNZ19R GGAGAAGAGAAGGAACAGAGA }\end{array}$ & $171-193$ \\
\hline 4 & $(\mathrm{CT})_{24}$ & $\begin{array}{l}\text { CNZ46F TTGGTTAGTATAGCCATGCAT } \\
\text { CNZ46R AACCATTTGTAGTATACCCC }\end{array}$ & $188-208$ \\
\hline 5 & $(\mathrm{CT})_{15}$ & $\begin{array}{l}\text { CN1G4F GTCGTCCTATACTCATCATCA } \\
\text { CN1G4R GATGCGTATGAGATGTGAGAG }\end{array}$ & $112-132$ \\
\hline 6 & $(\mathrm{CT})_{15}$ & $\begin{array}{l}\text { CN2A5F AAGGTGAAATCTATGAACACA } \\
\text { CN2A5R GGCAGTAACACATTACACATG }\end{array}$ & $150-190$ \\
\hline
\end{tabular}


Table 2. - Major amplified microsatellite PCR products and their estimated molecular weights for rattans.

\begin{tabular}{|c|c|c|c|c|c|c|c|c|c|}
\hline $\begin{array}{l}\text { Primers and size } \\
\text { range }\end{array}$ & Daemonorops & Korthalsia & Zalacea & $\begin{array}{l}\text { Calamus } \\
\text { simplicifolia }\end{array}$ & C. mannan & C. Ihwailesii & C. erectus & C. palustris & $\begin{array}{l}\text { Cocos } \\
\text { nucifera }\end{array}$ \\
\hline \multicolumn{10}{|c|}{ CNZ34 (131-185bp) } \\
\hline $131 \mathrm{bp}$ & + & + & + & + & + & + & + & + & + \\
\hline $140 \mathrm{bp}$ & - & + & + & - & - & + & - & - & + \\
\hline 150 bp & - & - & - & - & + & + & - & - & + \\
\hline $158 \mathrm{bp}$ & - & - & - & - & - & - & - & - & + \\
\hline $169 \mathrm{bp}$ & - & + & - & - & - & - & - & - & - \\
\hline $180 \mathrm{bp}$ & 1 & - & - & - & - & - & - & - & - \\
\hline \multicolumn{10}{|c|}{$\mathrm{CN} 2 \mathrm{~A} 5(150-190 \mathrm{bp})$} \\
\hline $150 \mathrm{bp}$ & - & + & + & + & + & + & + & + & - \\
\hline $168 \mathrm{bp}$ & - & - & - & - & + & - & - & - & - \\
\hline $190 \mathrm{bp}$ & + & + & + & + & + & + & + & - & + \\
\hline
\end{tabular}

Note: '+' indicates the presence of microsatellite PCR product and '-' indicates the absence.

Table 3. - Summary of microsatellite loci evaluated for rattans

\begin{tabular}{llcccc}
\hline $\begin{array}{l}\text { Microsatellite } \\
\text { primers } \\
\text { screened }\end{array}$ & $\begin{array}{l}\text { No. of } \\
\text { loci } \\
\text { amplified }\end{array}$ & $\begin{array}{l}\text { Mean no. of alleles } \\
\text { per locus }\end{array}$ & $\begin{array}{l}\text { Frequency of } \\
\text { alleles per locus }\end{array}$ & $\begin{array}{l}\text { No. of } \\
\text { polymorphic loci }\end{array}$ & $\begin{array}{c}\text { Polymorphism } \\
(\%)\end{array}$ \\
\hline CNZ34 & 11 & 4.18 & $0.125-1.0$ & 10 & 90.91 \\
CN2A5 & 4 & 4.0 & $0.375-0.625$ & 4 & 100 \\
\hline
\end{tabular}

different genera of rattans which belongs to the same family (Arecaceae) as coconut. The utility of the coconut microsatellite primer pairs to produce PCR-amplified products across the rattan genera was demonstrated. Of the six different locus specific coconut microsatellite primer pairs, two primer pairs viz., CNZ34 and CN2A5 yielded sufficiently good cross-species amplification in rattans. The PCR product inheritance patterns of the two microsatellite primer pairs, CNZ34 and CN2A5, are in accord with the previous results obtained for coconut (TEulat et al., 2000; Table 1 and 2). Both the primer pairs, CNZ34 and CN2A5, yielded a total of 11 and four PCR products respectively (Table 3 ). The mean number of alleles per locus (PCR-product) for both the primer pairs ranged from 4.0-4.18 (Table 3). The CNZ34 primer pair yielded $90.91 \%$ polymorphism, while CN2A5 primer pair yielded $100 \%$ polymorphism (Table 3 ). The major amplified PCR products (based on their intensity) and their estimated molecular weights in the different rattan genera and species are depicted in Table 2.

Cluster analysis employing Ward's algorithm (SNEATH and SOKAL, 1973) led to the segregation of the rattans into two distinct groups based on their genera. Two major clusters, with one having three genera (Korthalsia, Zalacca, Daemonorops), while the other having one genera (all the Calamus species) was obtained (Fig. 1). Within the latter cluster, rattan species from Indian origin (Calamus erectus from Northeastern Himalaya; C. thwaitesii from Western Ghats and C. palustris from Andaman and Nicobar Islands) grouped together, while those from Malaysia (C. mannan) and China (C. simplicifolia) grouped separately. This algorithmic method is well suited for diversity analysis since it groups the individuals into several clusters and has made it possi- ble to discriminate all the rattan genera examined. The pair-wise genetic distance (Ward's method; SNEATH and SOKAL, 1973) among rattan genera are presented in Table 4. For phylogenetic analysis, the binary matrix data was subjected to parsimony analysis using Winclada version 1.00.08 (NIXON, 2000). The most parsimonious tree (Fig. 2) with length $(\mathrm{L})=25$; a consistency index (CI) of 0.62 ; Retention index (RI) of 0.68 was presented. The bootstrap analysis (50\% majority-rule consensus) of the molecular data yielded a topology that was congruent with the cluster analysis. With C. nucifera as the out-group, the tree suggests that Korthalsia, Zalacca, Daemonorops formed a separate clade (with $71 \%$ bootstrap support) while all other Calamus species formed a monophyletic group. In the present study, there seems to be a clear differentiation of rattan genera based on the coconut locus specific microsatellite markers screened for cross-species amplification. Thus, the two coconut microsatellite markers, viz., CNZ34 and CN2A5, could be potentially used in reconstructing the molecular differentiation of rattans. The potential transferability of microsatellite primers across species of the same genus (CIPRIANI et al., 1999) and across genera of the same family has been reported in Leguminaceae (PEAKALL et al., 1998), Myrtaceae (ZUCCHI et al., 2002) and Fagaceae (ALDRICH et al., 2003). RosseTto (2001) reviewed the status of transferability of microsatellite markers to related taxa including many tree species.

We further examined the polymorphism for the microsatellite primer pairs (CNZ34 and CN2A5) within C. thwaitesii. Results showed lack of genetic variation indicating the highly conserved nature of these loci within a species (data not shown). While assessing 


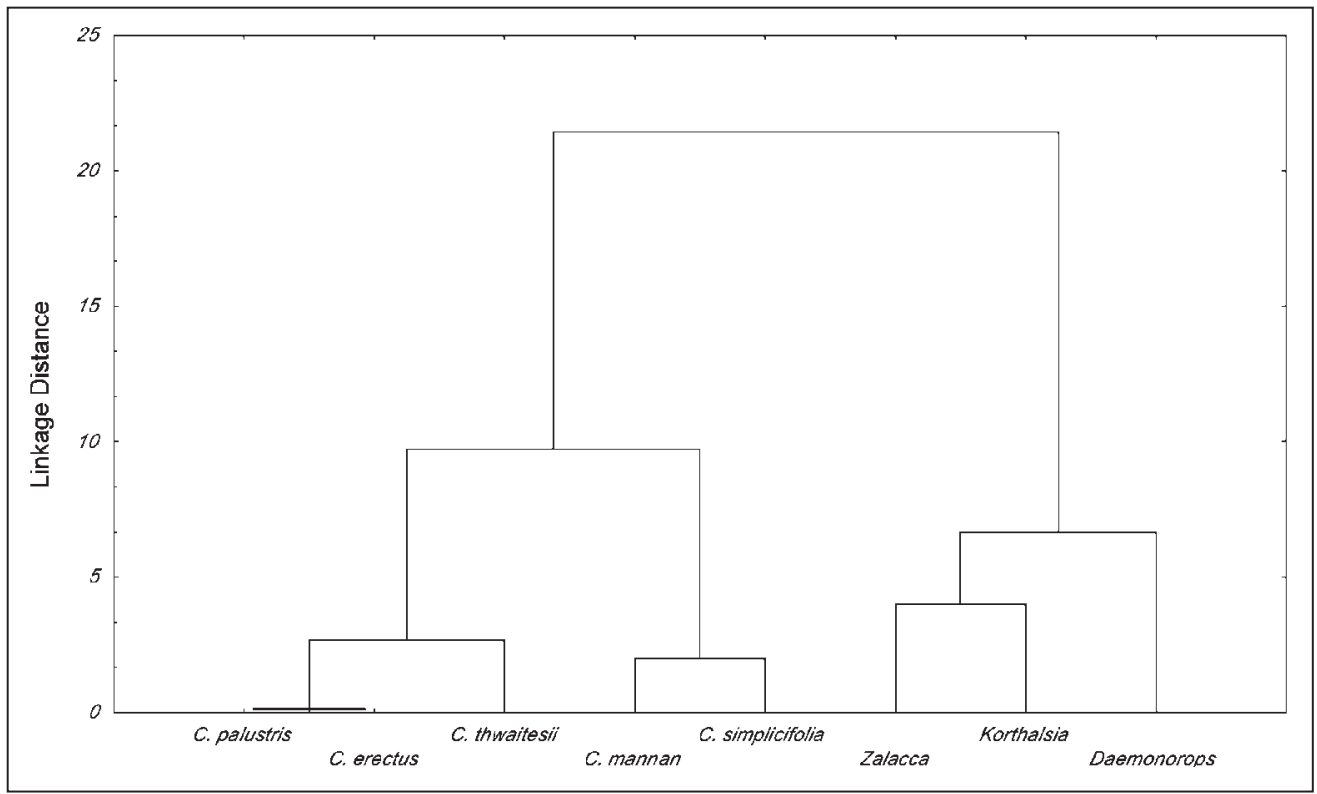

Figure 1. - Dendrogram clustering of rattans.

Table 4. - Pair-wise genetic distance values for rattans.

\begin{tabular}{|c|c|c|c|c|c|c|c|c|}
\hline $\begin{array}{l}\text { Pair-wise genetic } \\
\text { distance }\end{array}$ & Daemonorops & Korthalsia & Lalacca & $\begin{array}{l}\text { Calamus } \\
\text { simplicifolia }\end{array}$ & C. mannan & C. thwaitesii & C. erectus & C. palustris \\
\hline Daemonorops & 0 & & & & & & & \\
\hline Korthalsia & 6 & 0 & & & & & & \\
\hline Zalacca & 6 & 4 & 0 & & & & & \\
\hline C. simplicifolia & 9 & 9 & 7 & 0 & & & & \\
\hline C. mannan & 9 & 7 & 9 & 2 & 0 & & & \\
\hline C. thwaitesii & 10 & 8 & 10 & 5 & 5 & 0 & & \\
\hline C. erectus & 10 & 8 & 10 & 5 & 5 & 2 & 0 & \\
\hline C. palustris & 10 & 8 & 10 & 5 & 5 & 2 & 0 & 0 \\
\hline
\end{tabular}

cross-species amplification of eucalyptus microsatellite markers in Casuarinaceae, YASODHA et al. (2005) reported monomorphism within C. equisetifolia species. However, RoA et al. (2000) reported high levels of intraspecific variation in Manihot species using SSR markers. It has been observed that the microsatellite loci may exhibit decreasing variation as the evolutionary distance increases from the species used to develop the primer pairs (SUN and KIRKPATRIC, 1996), and this may perhaps explain the lack of variation found within C. thwaitesii. Knowledge of DNA sequence, being a prerequisite to designing appropriate primers for the PCR analysis, has restricted the development and application of microsatellite markers to a few of the most agronomically important crop species. Most of the microsatellites reported have been developed from the public domain (GenBank database) which are generally available for the model organisms only. The knowledge of genome sequence is hardly available for most of the forest species like rattans. Hence, cross-species amplification, if possible, may facilitate more widespread use of microsatellites across species and genera.

In summary, the coconut microsatellite markers could be successfully used to unravel the molecular differentiation of the four rattan genera. However, it could be of only limited use in determining genetic diversity within the same rattan species. Our study emphasizes the importance of conducting pilot studies to establish the utility of the planned genotyping system before largescale projects be initiated in rattans.

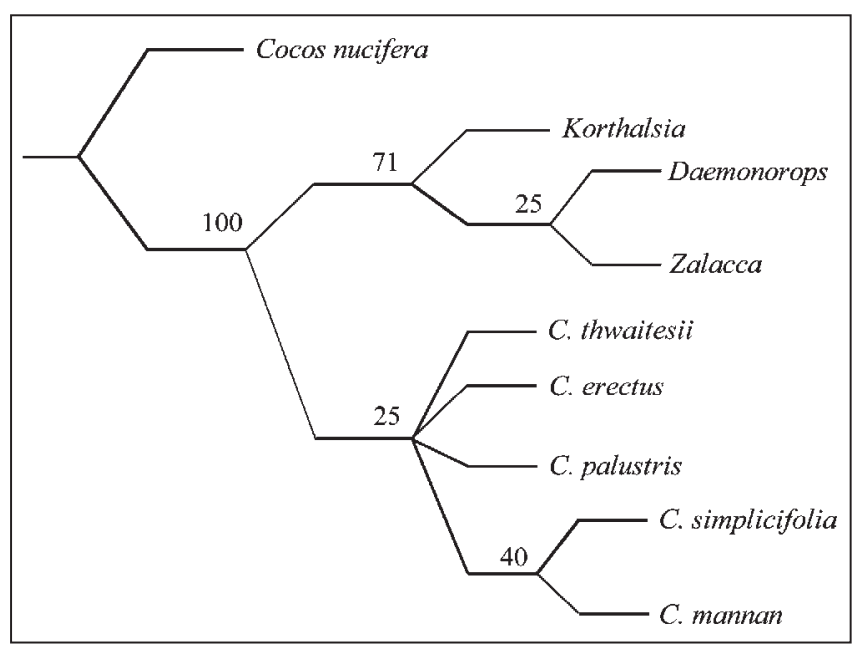

Figure 2. - Phylogenetic tree for rattans $(\mathrm{L}=25$; $\mathrm{CI}=0.62$; $\mathrm{RI}=0.68$ ). Bootstrap values are given above the branches. Cocos nucifera was used as an out-group. 


\section{Acknowledgements}

Thanks are due to the International Plant Genetic Resources Institute (IPGRI), Rome and Malaysia and Department of Biotechnology (DBT), New Delhi, India for supporting the study. The support and co-operation of Dr. RENUKA C. (KFRI, Kerala) and the Karnataka Forest Department (KFD) is gratefully acknowledged.

\section{References}

Aldrich, P. R., M. Jagtap, C. H. MichleR and J. RomeroSEVERSON (2003): Amplification of north American red oak microsatellite markers in European white oaks and Chinese chestnut. Silvae Genet 52: 176-179.

BASU, S. K. (1985): The present status of rattan palms in India - An overview. In: Proceedings of the Rattan Seminar, Edited by WANG and MANOKARAN, Kuala Lumpur, Malaysia, pp. 77-94.

Cipriani, G., G. Lot, W. G. Huang, M. T. Marrazzo, E. Peterlunger and R. Testlin (1999): AC/GT and AG/CT microsatellite repeats in peach (Prunus persica (L) Batsch): Isolation, characterization and crossspecies amplification in Prunus. Theor. Appl. Genet. 99: 65-72.

Clauss, M. J., H. Cobban and T. Mitchell-Olds (2002): Cross-species microsatellite markers for elucidating population genetic structure in Arabidopsis and Arabis (Brassicaeae). Mol. Ecol. 11: 591-601.

DoYLE, J. J. and J. S. DoYLE (1987): A rapid DNA isolation procedure for small quantities of fresh leaf tissue. Phytochem. Bull. 19: 11-15.

DRANSFIELD, J. (1996): The rattan taxonomy and ecology. In: Proceedings of Training Courses Cum Workshop, Rattan: Taxonomy, Ecology, Silviculture, Conservation, Genetic Improvement and Biotechnology, Edited by RAO, A. N. and RAMANATHA RAO, V. IPGRI-APO and INBAR, Sarawak, p. 114.

Jones, R. C., J. McNally and M. Rossetto (2002): Isolation of microsatellite loci from a rainforest tree Elaeocarpus grandis (Elaeocarpaceae), and amplification across closely related taxa. Mol. Ecol. Notes 2: 179-181.

KARHU, A., J. H. Dietrich and O. SAVOlainen (2000): Rapid extraction of microsatellite sequences in pines. Mol. Biol. Evol. 17: 259-265.

LakshmanA, A. C. (1995): Rattans of South India. Evergreen Publishers, Bangalore, India, pp. 1-179.

Lyngdoh, N., S. H. SANTOSh, B. T. RAMESha, M. NAGESwara Rao, G. Ravikanth, B. Narayani, K. N. GanesHAIAH and R. UMA SHAANKER (2005): Rattan species richness and population genetic structure of Calamus flagellum in North-Eastern Himalaya, India. J. Bamboo Rattan 4: 293-307.

Nixon, (2000): WinClada. Version 1.00.08. Published by the author, Ithaca, NY.

Peakall, R., S. Gilmore, W. Keys, M. Morgante and A. RAFALSKI (1998): Cross-species amplification of soyabean (Glycine max) simple sequence repeats (SSRs) within the genus and other legume genera, implications for the transferability of SSRs in plants. Mol. Biol. Evol. 15: $1275-1287$.

RAO, A. N. and R. V. RAO (1998): Priority Species of Bamboo and Rattan. IPGRI-APO, Serdang, Malaysia.

Ravikanth, G., K. N. Ganeshaiah and R. Uma ShaAnKeR (2001): Mapping genetic diversity of rattans in the central Western Ghats: Identification of hot-spots of vari- ability for in-situ conservation. In: UMA SHAANKER, R., GANeShaiAh, K. N. and BAWA, K. S. (Eds). Forest genetic resources: Status, threats and conservation strategies. Oxford Publications, New Delhi, India, pp. 69-83.

RenukA, C. (2001): Palms of India: status, threats and conservation strategies. In: UMA SHAANKER, R., GANESHAIAH, K. N. and BAWA, K. S. (Eds). Forest genetic resources: Status, threats and conservation strategies. Oxford Publications, New Delhi, India, pp. 197-209.

Roa, A. C., P. Chavarriaga-Aguirre, M. C. Duque, M. M. Maya, M. W. Bonierbale, C. Iglesias and J. Tohme (2000): Cross-species amplification of cassava (Manihot esculenta) Euphorbiaceae microsatellites: allelic polymorphism and degree of relationships. Amer. J. Bot. 87: 1647-1655.

RossetTo, M. (2001): Sourcing of SSR markers from related plant species. In: HenRY, R. J. (Ed). Plant genotyping: the DNA fingerprinting of plants. CAB international, Oxford, pp. 210-224.

Scott, I. A. W., C. M. J. Hayes, S. Koegh and S. F. MorriSON (2001): Isolation and characterization of novel microsatellite markers from the Australian water skin Eulamprus kosciuskoi and cross-species amplification in other members of the species-group. Mol. Ecol. Notes 1: $28-30$.

SNeAth, P. H. A. and R. R. SoKAl (1973): Numerical taxonomy. San Francisco, Freeman.

STATSOFT (1993): Statistica ver 4.5. Statsoft, Inc., USA.

Sun, H. S. and B. W. KiRKPATRIC (1996): Exploiting dinucleotide microsatellites conserved among mammalian species. Mamm. Gen. 7: 128-132.

Teulat, B., C. Aldam, R. Trehin, P. Lebrun, J. H. A. Barker, G. M. ARnold, A. KarP, L. Baudouin and F. ROGNON (2000): An analysis of genetic diversity in coconut (Cocos nucifera) populations from across the geographic range using sequence tagged microsatellites (SSRs) and AFLPs. Theor. Appl. Genet. 100: 764-771.

Turpeinen, T., T. Tenhola, O. Manninen, E. Nevo and E. Nissila (2001): Microsatellite diversity associated with ecological factors in Hordeum spontaneum populations in Israel. Mol. Ecol. 10: 1577-1591.

YASODHA, R., M. GHOSH, R. Sumathi and K. GuRUmuRThy (2005): Cross-species amplification of eucalyptus SSR markers in Casuarinaceae. Acta. Bot. Croat. 64: 115-120.

YeH, F. C., R. C. YANG and T. Boyle (1999): POPGENE, Version 1.31. CIFOR and Univ. of Alberta, Edmonton, Alberta, Canada.

WiCKNESWARI, R. and T. J. BOYLE (2000): Effects of logging and other forms of harvesting on genetic diversity in humid tropical forests. In: Young, A., Boshier, D. and Boyle, T. (Eds). Forest Conservation and Genetics Principles and Practice. CSIRO Publishing, Australia, pp. 115-122.

Williamson, J. E., R. M. Huebinger, J. A. Sommer, E. E. LOUIS, JR. and R. C. BARBER (2002): Development and cross-species amplification of 18 microsatellite markers in the Sumatran tiger (Panthers tigris sumatrae). Mol. Ecol. Notes 2: 110-112.

Zucchi, M. I., R. P. V. Brondani, J. B. Pinheiro, C. BronDANI and R. VENCOVSKY (2002): Transferability of microsatellite markers from Eucalyptus spp. to Eugenia dystenterica (Myrtaceae family). Mol. Ecol. Notes 2: 512 . 